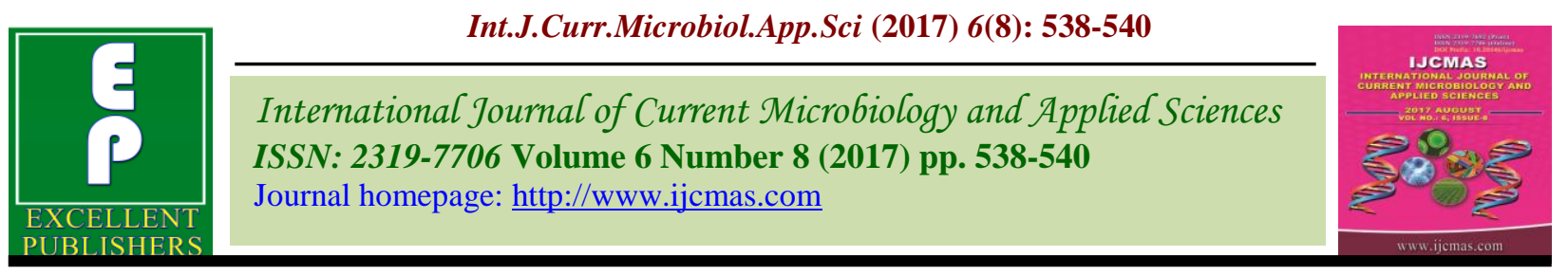

Case Study

https://doi.org/10.20546/ijcmas.2017.608.069

\title{
Dystocia Due to Breech Presented Foetal Anasarca in a Marwari Doe: A Case Report
}

\author{
Devasee Borakhatariya*, Pravin Kandhani, Rajesh Kalsariya and Kunal Mungad \\ Polytechnic in Animal Husbandry, College of Veterinary Science and Animal Husbandry, \\ Junagadh Agricultural University, Junagadh, Gujarat-362001, India \\ *Corresponding author
}

\section{A B S T R A C T}

\begin{tabular}{|c|}
\hline Keywords \\
\hline $\begin{array}{l}\text { Dystocia, Doe, } \\
\text { Foetal Anasarca, } \\
\text { Marwari, } \\
\text { Obstetrical Knife. }\end{array}$ \\
\hline Article Info \\
\hline $\begin{array}{l}\text { Accepted: } \\
\text { 04 June } 2017 \\
\text { Available Online: } \\
10 \text { August } 2017\end{array}$ \\
\hline
\end{tabular}

Foetal anasarca is characterized by wide-spread swelling of the skin due to subcutaneous and inter-muscular accumulation of fluid in muscles, umbilicus and legs resulted into the formation of the generalized oedema. Present case reports the successful management of dystocia due to foetal anasarca in a Marwari doe.

\section{Introduction}

The major contributory factor in the economic losses in goat farming is the dystocia as a result of which death of the either foetus or dam occurs. Reports of the foetal anasarca are very less reported in small ruminants. Foetal anasarca is characterized by wide-spread swelling of the skin due to subcutaneous and inter-muscular accumulation of fluid in muscles, umbilicus and legs resulted into the formation of the generalized oedema (Roberts, 1986). The affected foetus is usually carried to term, and concern is caused by the lack of progress in second-stage labour. This is due to the great increase in foetal volume caused by the excess of fluid in the subcutaneous tissues, particularly of the head and hind limbs (Roberts, 2004). In the case of the head, there is so much swelling that the normal features are masked and the resultant appearance is quite grotesque. It is an interesting point that an undue proportion of these anasarcous foetuses are presented posteriorly, in which case the enormous swelling of the presenting limbs is very conspicuous (Prabaharan et al., 2016). Generally, in such cases surgical manoeuvour is required however present communication reports a successful per vaginal delivery of the kid.

\section{Case history and clinical observation}

A 3-year old pluriparous Marwari doe with full term gestation was presented at the clinic 
with the history of discomfort, constant abdominal straining since four hours, and ruptured water bag. Doe was earlier attended by local quack but was unable to deliver foetus. The external examination revealed swollen vulva, continuous abdominal straining, and ruptured water bag. Physiological parameters recorded were in the normal rage except, rectal temperature (103.8 $\left.{ }^{\circ} \mathrm{F}\right)$ and slight tachycardia. Per vaginal examination revealed dilated cervix, posterior (breech) presentation and dorso-sacral position of the kid, having oedematous mild distended abdomen with absence of the vital reflex in the kid.

\section{Results and Discussion}

After proper lubrication of the birth canal using liquid paraffin and rinsing the perianal region with the $1 \%$ potassium permanganate lotion, attempts were made to deliver the kid by the forced traction, but it was failed due to large sized kid. Hence, it was decided to drain out the anasarcous fluid with the help of the obstetrical knife. Per vaginally, knife was inserted and anasarcous fluid was evacuated by puncturing abdomen. Kid size got reduced and with further lubricating the birth canal, kid was delivered. Per vaginal re-examination did not reveal another foetus in the womb.

Fig.1 Anasarcous bulldog kid

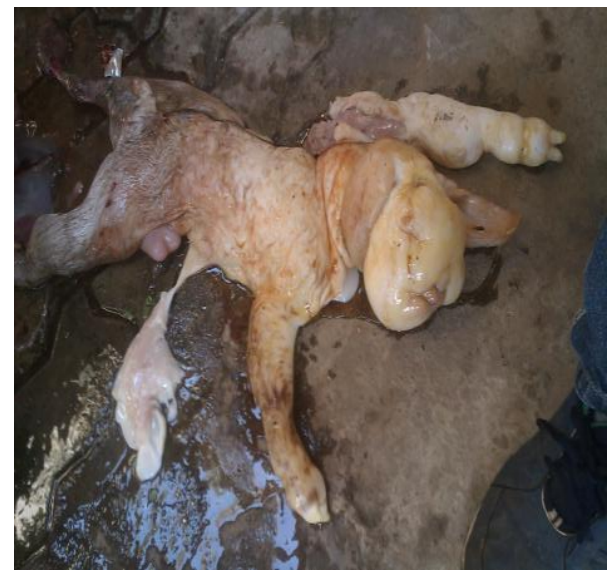

Dead kid showed enormous fluctuating swelling of all four legs. Further, head has a disproportionate conformation just like a bull dog appearance with short stumpy neck (Photo I). The dam was administered with injections Meloxicam (Melonex, Intas Pharma, Ahmedabad) IM @ 0.25 mg/b. wt., Ceftriaxone and Tazobactam2250 mgIM, 2 ml Vitade IM, $5 \mathrm{ml}$ Vitamin B complex IV (Tribivet, Zydus AH), and 4 boluses of Furea were placed in uterus. Therapy continued for three more days resulted into uneventful recovery of doe with good milk production. Foetal anasarca has been observed mainly in calf, but occasionally in kids and foals (Craig,
2000). A fetus with anasarca may be prone to dystocia because the generalized edema will cause the fetus not to pass through the pelvic canal (Noakes et al., 2001). Therefore, surgical intervention is usually required for the delivery of oversized anasarcous fetus (Kumar et al., 2005); however, in the present case the successful vaginal delivery of an anasarcous kid is depicted. Roberts (2004) stated that foetal anasarca may develop in a single foetus or one of the twins and was due to simple autosomal recessive gene. Rarely mild hydrops of the amnion or allantois and oedema of the placenta may accompany foetal anasarca (Jayachandra et al., 2013). Most 
anasarcous foetus is expelled dead. The fluid effusion accumulation in subcutaneous space might be due to lack of lymphnodes and existence of autosomal recessive allele which affect the embryological development of normal lymph nodes (Chandrasekaran et al., 2015; Monteagudo et al., 2002).

\section{References}

Chandrasekaran, D., Selvakumar, S., Suresh Kumar, R., Pothiapan, P., Ananga Kumar Das and Balasubramanian, S. 2015. Per vaginal delivery of anasarcous foetus in a Tellicherry doe. Indian J. Anim. Reprod., 36(1): 60-61.

Craig, J.F. 2000. Flemings's Vet. Obstetrics, Green World Publishers, London, U.K., p. 271-273.

Jayachandra, H.K., Kulkarni, H., Magadum, S. and Badami, S. 2013. Dystocia due to foetalanasarca with achondroplasia in a goat - a case report. Int. J. Food and Agri. Sci., 3(3): 116-118.

Kumar, S., Bhatt, P., Prasad, J.K., Rawat,
A.K., Maurya, S.N. and Kumar, S. 2005. Dystocia due to fetal anasarca in a crossbred cow. Indian J. Anim. Reprod., 26: 177-178.

Monteagudo, L., Lujan, L., Tejedor, T., Climent, S., Acin, C., Navarro, A. and Arruga, M.V. 2002. Fetal anasarca (Hydrops foetalis) associated with lymphoid tissue agenesis possibly due to an autosomal recessive gene defect in sheep. Theriogenol., 58: 1219-1228.

Noakes, D.E., Parkinson, D.J. and England, G.C.W. 2001. Arthur's Vet Reproduction and Obstetrics, $8^{\text {th }}$ edn., Saunders Harcourt, India. pp. 118-20.

Prabaharan V., Sivakumar, A., Jayaganthan, P., Raja, S., Vijayarajan, A. and Sathesh Kumar, S. 2016. Dystocia due to fetal anasarca and ascities with live fetus in a doe. Int. J. Sci., Environ. Tech., 5(4): 2586-2589.

Roberts, S.J. 1986. Vet. Obstetrics and Genital Dis. Theriogenol., $3^{\text {rd }}$ edn., Woodstock, Edwards Brothers Inc. USA, pp. 283-350.

\section{How to cite this article:}

Devasee Borakhatariya, Pravin Kandhani, Rajesh Kalsariya and Kunal Mungad. 2017. Dystocia Due to Breech Presented Foetal Anasarca in a Marwari Doe: A Case Report. Int.J.Curr.Microbiol.App.Sci. 6(8): 538-540. doi: https://doi.org/10.20546/ijcmas.2017.608.069 